\title{
Implementation of Standard Form Contract in Financing Agreement of Sharia Banking in Islamic Law Perspective
}

\author{
Audina Noor Arifa*; Burhanudin Harahap \\ Faculty of Law, Universitas Sebelas Maret, Indonesia \\ Email: audinanoorarifa@gmail.com
}

http://dx.doi.org/10.18415/ijmmu.v5i4.420

\begin{abstract}
This study analyzed the implementation of standard form contract in financing agreement of Sharia banking in Islamic law perspective. This study aimed at discovering the process of mutual agreement on standard form contract of a financing agreement in Sharia banking. This study employed an empirical legal study. It was aimed at studying one or more social phenomena by analyzing it. This study found that during the process of mutual agreement on standard form contract between the bank and the customer, the element of ijab and qabul had been satisfied since the bank had made an offer and the customer accept the bank offer. However, it was found that the customer did not possess a right to change the content of the standard form contract. If there was a customer felt an objection, the requirement of a valid agreement is not satisfied since there is al-ikrah or compulsion factor in accepting the agreement. For the agreement is not met, the agreement will be considered as broken (fasid) and can be annulled.
\end{abstract}

Keywords: Standard form Contract; Agreement; Financing Agreement; Sharia Bank; Islamic Law

\section{Introduction}

Indonesia as the largest Muslim country around the globe demands a bank that performs its activity based on the principle of Sharia. By the enactment of Law no. 21 of 2008, the bank and Sharia bank established based on Law no. 7 of 1992 which was amended by Law no. 10 of 1998 obtain specific legal basis which is stronger and more firm. ${ }^{1}$ Sharia banking is a financial institution that performs its business activities based on Sharia principles. The reasoning background why Sharia principle become the legal source of economic and banking system is because the standing of Sharia is a revelation of Allah for humankind to implement. ${ }^{2}$

Based on Law no. 21 of 2008 regarding Sharia Banking, it is stipulated that Sharia principle the Sharia banks shall adhere to is the one enacted by National Sharia Assembly-Indonesian Ulema Assembly which is then expressed in Bank Indonesia Regulation. ${ }^{3}$

\footnotetext{
${ }^{1}$ Sutan Remy Sjahdeini. (2015). Perbankan Sharia Produk-Produk dan Aspek-Aspek Hukumnya, Prenadamedia Group, Jakarta, p. 31-32.

${ }^{2}$ Burhanuddin S. (2010). Aspek Hukum Lembaga Keuangan Sharia, Graha Ilmu, Yogyakarta, p. 17.

${ }^{3}$ Sutan Remy Sjahdeini, Op.Cit., p. 2.
} 
In particular business domain, for example, trading and banking, there is a tendency to use what so called as standard form contract. It is a contract in which a party (the company) has been unilaterally determined its content and use it continuously with many parties/ consumers of the company. Most of the content of the standard form contract has been determined by the company and is non-negotiable, and some of the content is intentionally left blank to provide a space for the consumers to negotiate, which are filled after the agreement has been reached. ${ }^{4}$

In its implementation of the financing agreement, Sharia Banks use standard form contract. In praxis, although Sharia bank use standard form contract to make financing agreement more efficient, it leads to many debates on its implementation. The inequality occurs since the standard form contract is made unilaterally by the Sharia bank whose standing is stronger than the consumer as the weak party. The content of the standard form contract often disserves the consumers since the standings of the two parties are not equal. The consumers only have a take it or leave it option for the contract to be agreed between the Sharia Bank and them. Usually, the consumer has to choose take it option since the consumer is the party who needs bank, without having a chance to negotiate.

The use of standard form contract in Sharia banking is related to the Sharia principles regulated in The regulation of Bank Indonesia number 10/16/PBI/2008 about the amendment on the Regulation of Bank Indonesia number 9/19/PBI 2007 about The Implementation Of Sharia Principle In Fund Collection And Distribution As Well As Sharia Bank Services Activities, article 2 paragraph (3) about the Fulfillment of Sharia principles as meant in paragraph (2) is implemented by satisfying the main provision of Islamic law namely justice and equality ('Adl wa tawazun), avail (maslahah), and universalism (alamiyah) as well as containing no gharar, maysir, riba, zalim, and forbidden object.

Grounded on the description above, the researcher was interested in conducting more in-depth study regarding to what extent the implementation of standard form contract in financing agreement on sharia banking until finally the two parties reach mutual agreement on the standard form contract which will be viewed from Islamic law perspective. That study will be expressed in a writing entitled: THE IMPLEMENTATION OF STANDARD FORM CONTRACT IN FINANCING AGREEMENT OF SHARIA BANKING IN ISLAMIC LAW PERSPECTIVE, with its problem stated as: how is the process of mutual agreement on standard form contract of financing agreement on sharia banking.

\section{Methodology}

This study employed empirical legal study. Soerjono Soekanto stated that empirical legal study is a study that is grounded on a particular method, systematic, and reasoning, which is aimed at studying one or several social phenomena by analyzing it. In addition, in-depth observation towards such social fact was also conducted to establish a solution for an issue emerges because of the phenomena. In empirical legal study, the data being studied is initially secondary data, then is followed by study on primary data in the field or the society. ${ }^{5}$

The data collection technique of the study was field study in the form of interviews and literature study. While the data analysis technique of the study was qualitative data analysis. Matthew B. Miles and A. Michael Huberman assert that the things within qualitative analysis are, the data emerge in the form of words and is not numerical. Those data may have been collected through various methods (observation, interviews, document abstract, tape recording), and are usually processed before they are ready to use (through recording, typing, editing, or translating). However, the qualitative analysis still uses words,

\footnotetext{
${ }^{4}$ Gemala Dewi. (2004). Aspek-Aspek Hukum Dalam Perbankan \& Perasuransian Sharia di Indonesia, Prenada Media, Jakarta, p. 186.

${ }^{5}$ Soerjono Soekanto. (2010). Pengantar Penelitian Hukum, Penerbit Universitas Indonesia (UI-Press), Jakarta, p. 5-6.
} 
which are usually arranged into broadened text. The analysis comprises three simultaneous activities namely data reduction, data display, and conclusion drawing/ verification. ${ }^{6}$

\section{Discussion}

\section{The Process of Mutual Agreement on Standard Form Contract of Financing Agreement in Sharia Banking}

The use of standard form contract in Sharia banking is related to the Sharia principles regulated in the regulation of Bank Indonesia number 10/16/PBI/2008 about the amendment on the Regulation of Bank Indonesia number 9/19/PBI 2007 about The Implementation Of Sharia Principle In Fund Collection And Distribution As Well As Sharia Bank Services Activities. The Sharia principles mentioned in article 2 paragraph (3) of The regulation of Bank Indonesia number 10/16/PBI/2008 about the amendment on the Regulation of Bank Indonesia number 9/19/PBI 2007 about The Implementation Of Sharia Principle In Fund Collection And Distribution As Well As Sharia Bank Services Activities about the Fulfillment of Sharia principles as meant in paragraph (2) is implemented by satisfying the main provision of Islamic law namely justice and equality ('adl wa tawazun), avail (maslahah), and universalism (alamiyah) as well as containing no gharar, maysir, riba, zalim, and forbidden object.

In the use of standard form contract, the most related to the Sharia principles is justice and equality principle ('adl wa tawazun) since there is inequal standing between the customer as the weak party and the bank whose standing is higher as the strong party. The inequality occurs since the standard form contract is made unilaterally by the Sharia bank whose standing is stronger than the consumer as the weak party. The content of standard form contract often disserves the consumers since the standings of the two parties are not equal. The consumers only have a take it or leave it option for the contract to be agreed between the Sharia Bank and them. Usually, the consumer have to choose take it option since the consumer is the party who needs bank, without having a chance to negotiate.

The finding of the study obtained by the researcher was: ${ }^{7}$

\section{a. Funding Grant Agreement or SP3}

Prior to the customer make an agreement, the customer will be given Funding Grant Agreement or SP3. It contains of terms and conditions of funding so that the customer application for financing can be approved. This agreement contains of funding types, allocation types, maximum funding, bank profit margin, bank selling price, monthly installment, installment term, fund to be provided for administration, Notary, life insurance premium, fire insurance premium, SKMHT (Authorization for Assignment of Mortgage) or APHT (deed of grant of mortgage), appraiser, last month installment (blocked), minimum deposit, and amount, arrear fine, security, funding disbursement requirement, financing agreement signing, insurance, and so forth. If the customers agree with the content of SP3, the agreement proceeds, whereas if the customer do not agree with the content of SP3, the agreement cannot be proceeded. If the customer has agreed with the term and condition in SP3, the customer shall sign the copy of SP3 on the stamp duty of Rp. 6000,- and return it to the bank no more than 60 (sixty) workdays since SP3 is issued and is equipped with the original passbook if the funding is to be realized. SP3 is considered as void or is

\footnotetext{
${ }^{6}$ Matthew B. Miles and A. Michael Huberman. (2009). Analisis Data Kualitatif Buku Sumber Tentang Metode-Metode Baru, Penerbit Universitas Indonesia (UI-Press), Jakarta, p. 15-16.

${ }^{7}$ Interview with Mr. Rahmad Budianta, Consumer Financing services of BTN Sharia Branch office Surakarta, Mr. M. Hakikal Kurniawan, Financing support manager of BRI Sharia branch office of Surakarta and Mrs. Fitri Juariyah, Financing Administration Head of BNI Sharia Branch Office Surakarta.
} 
not valid if the customer has not completed the requirements and provisions within SP3 until the determined period of time.

\section{b. The Process of Mutual Agreement on the Standard Form Contract of Financing Agreement}

If the customer agrees with SP3, so the customer is automatically considered as agree since the agreement emerges from it. When the customer receives SP3, the financing scheme will be explained. The customer shall agree to proceed the contract. Two banks use private agreement in establishing the contract, and there was one bank that used the notarial contract. For notarial contract, when the bank is going to make an agreement, the bank will explain to the customer by the notary read it out for the customer, and the customer, him/herself, read it by the bank assistance. While, for private agreement, during the agreement, the bank will explain it, what may and may not be done by the customer during the agreement. The bank will read out the point in the agreement technically, not the entire content but only the essential points, like article 1, article 3 where the bank will explain what is murabahah agreement, and the portion shall be paid in accordance with the ones mentioned in SP3, the agreement terms and condition, and so forth.

After the bank read it out, if the customer agrees with this contract, the customer will sign on it, and he/ she will receive the copy of the contract. However, if the customer disinclines the contract although he/she has initially agreed with it, the process of contract signing will be postponed. If the customer is unwilling with the article 1 of the contract which contains SP3 that is initially agreed, the contract is considered as fail for there is no agreement. The customer also cannot change the content of article 2 and the others since this article is unchangeable standard article. This occurs on murabahah agreement where it is unchangeable.

If the customer who initially agree the SP3 and then is immediately unwilling when the agreement is read out, if the customer is unwilling with the content of other articles as mentioned in SP3, it can be discussed, and the process of agreement signing is postponed for the agreement has not been reached. For instance, the customer is unwilling about the $1 \%$ administration fee and ask for $0.5 \%$, the bank and the customer will have a negotiation, then the bank propose a draft to the committee, if the draft is approved, the content can be changed, but if the committee does not agree, the content of the contract will not be changed.

The process of ijab qabul in this agreement is the in the form of offer, proposed to the committee, then the committee' decision will be used. If the customer agrees after it is changed, the agreement proceeds, when the parties have agreed, the agreement will be signed. If the customer still does not agree, the contract is canceled.

\section{c. Customer Right in Financing Agreement}

The customer right to change the content of the financing agreement can only be done to some specific articles which are intentionally left blank to be filled under the agreement between the customer and the bank. However, the standard clause cannot be changed although the customer is unwilling with the content of the standard form contract. Whereas, its implementation in musyarakah dan mudharabah is more flexible. The customer may change the clause on profit-sharing and other clauses if he/she does not agree with the content of such standard form contract. If the customer agrees with the contract, for there is an agreement, the agreement can be signed and be implemented. 
The customer cannot disagree with certain clauses of an agreement since he/she must agree with all the content of the agreement. If the customer is unwilling, the agreement is annulled. To date the customer does not understand the entire content of the contract well. Only few of them do. Most of the customers only know and listen to the certain articles such as term, default, and others.

If there are points the customer disagrees, the process of agreement signing will be postponed by the bank, and the bank will have a consultation with the division responsible for it such as committee or legal division of the bank. There was a case where the customer is unwilling with the agreement content, there was a misunderstanding between the bank and the customer, if this situation happens, the customer objection will be accommodated and be sent to the committee. However, the clauses are still standards. We cannot change the clear things such as dispute settlements. This is different with the clause required by the committee, the content of standard form contract is unchangeable. The changeable things are only those related to the content of other articles where its content can be added or reduced if the customer finds it quite burdensome through the committee, there is addendum if the committee approves it. In the implementation, the content of the clauses of musyarakah agreement is more flexible than murabahah agreement.

There was also a case where the customer was unwilling with the article of default because there is a phrase "The entire property as the security", the customer was unwilling to give all his properties as security, and then the bank explained about it to him, and he could accept the agreement.

\section{d. The Standard Form Contract Cannot be Changed by the Customer}

At the end, if the customer was unwiling with the bank' financing contract, the customer can only change the ones which are not standard, only the certain points which was intentionally left blank since the beginning for the customer to fill based on the deal between the bank and the customer. The content of the standard form contract of the financing agreement cannot be changed by the customer.

Agreement legal instrument in Islamic sharia is the fulfillment of the Rukun and the requirement of an agreement. Rukun is an essential element that must exist in an agreement or transaction, while requirement is the element that must exist to complete rukun. If rukun is not satisfied, the agreement is not legitimate and can be annulled. In case rukun is not satisfied in the form of the object of agreement, where the agreement is on goods forbidden by Islamic law, the agreement is null and void. While, if other rukun and requirements are not satisfied, the agreement is not null and void, however it still illegitimate and can be asked for annulment. According to the Muslim scholars, rukun of agreement is a deal to bind (shighat al-'aqd), the parties in agreement (al-muta'aqidain/ al-'aqidain), object of the agreement (alma'qud alaih/ mahal al-'aqd), and the purpose of agreement (maudhu' al-'aqd). ${ }^{8}$

The things concerning various Islamic law resources the Sharia banks shall use for guideline in running its business activities to avoid violating Sharia principle as regulated by Sharia banking law is essential since muamalah agreement the sharia bank makes which violates the Sharia principle will result in the null and void of such muamalah agreement. ${ }^{9}$

In establishing muamalah agreement, there are some requirements the parties shall concern with so that the agreement is legitimate and is not null and void. The first requirement shall be met is the existence of $i j a b$ and qabul between the parties who make the agreement. According to common law, a contract occurs when it is preceded by an offer proposed by a party who wants to make an agreement with

\footnotetext{
${ }^{8}$ Fathurrahman Djamil, Penerapan Hukum Perjanjian dalam Transaksi di Lembaga Keuangan Sharia, Sinar Grafika, Jakarta, 2012, p. $27-28$.

${ }^{9}$ Sutan Remy Sjahdeini, Op.Cit., p. 3.
} 
another party. In Islamic law, offer is called as ijab. An offer only occurs if the offer made by a party is accepted by the other party (acceptance). In Islamic law, acceptance is called as qabul. ${ }^{10}$

Shighat al-aqd refers to the way how the statement of self-binding is made. Shighat al-aqd is an essential pillar of an agreement. In fiqh literature, shighat al-aqd is usually translated in the form of ijab and qabul. This shighat (ijab-qabul) establishes a mutual assent between the parties. It happens because the essence of shighat is a compliance between the parties who make agreement based on freedom, equality, and justice. ${ }^{11}$

The requirement of legitimate agreement refers to anything required by syara' to warrant the legitimacy of the agreement effect (litartibi atsaril aqdi). For the agreement is not met, the agreement will be considered as broken (fasid) and can be annulled. According to Hanafiyah scholars, an agreement is considered as legitimate if it does not contain six elements namely al-jahalah (obscurity of price, types, specification, payment term, insurers), al-ikrah (compulsion), attauqit (time limitation), al-gharar (vagueness or fictitious), al-dharar (an element of danger/harm), and al-syarthul fasid (broken requirement,such as a requirement for the purchaser to sell the item back to the seller with a lower price). ${ }^{12}$

Based on the findings of the study, it was found that during the process of mutual agreement on standard form contract between the bank and the customer, the element of ijab and qabul had been satisfied since the bank had made an offer and the customer accept the bank offer. However, it was found that the customer did not possess a right to change the content of standard form contract. If the customer is unwilling, for some articles within the agreement, the customer can change the content of the article if the committee or legal division deal with it, however the standard articles in the form of definition, legal domicile, and others cannot be changed by the customer. The requirement of valid agreement is not satisfied since there is al-ikrah or compulsion factor in accepting the content of the standard form contract. For the agreement is not met, the agreement will be considered as broken (fasid) and can be annulled.

\section{Conclusion}

During the process of mutual agreement on standard form contract between the bank and the customer, the element of ijab and qabul had been satisfied since the bank had made an offer and the customer accept the bank offer. However, it was found that the customer did not possess a right to change the content of standard form contract. If there was a customer felt an objection, the requirement of valid agreement is not satisfied since there is al-ikrah or compulsion factor in accepting the agreement. For the agreement is not met, the agreement will be considered as broken (fasid) and can be annulled.

\section{References}

Dewi, Gemala. (2004). Aspek-Aspek Hukum dalam Perbankan \& Perasuransian Sharia di Indonesia. Jakarta: Prenada Media.

Djamil, Fathurrahman. (2012). Penerapan Hukum Perjanjian dalam Transaksi di Lembaga Keuangan Sharia. Jakarta: Sinar Grafika.

\footnotetext{
${ }^{10}$ Sutan Remy Sjahdeini, Op.Cit., p. 129.

${ }^{11}$ Fathurrahman Djamil, Op.Cit., p. 28-29.

${ }^{12}$ Ibid, pp. 41.
} 
Miles, Matthew B. dan A. Michael Huberman. 2009. Analisis Data Kualitatif Buku Sumber Tentang Metode-Metode Baru. Jakarta: Penerbit Universitas Indonesia (UI-Press).

Peraturan Bank Indonesia Nomor 10/16/PBI/2008 tentang Perubahan Atas Peraturan Bank Indonesia Nomor 9/19/PBI/2007 tentang Pelaksanaan Prinsip Sharia dalam Kegiatan Penghimpunan Dana dan Penyaluran Dana serta Pelayanan Jasa Bank Sharia.

S., Burhanuddin. (2010). Aspek Hukum Lembaga Keuangan Sharia. Yogyakarta: Graha Ilmu.

Sjahdeini, Sutan Remy. (2015). Perbankan Sharia Produk-Produk dan Aspek-Aspek Hukumnya. Jakarta: Prenadamedia Group.

Soekanto, Soerjono. (2010). Pengantar Penelitian Hukum. Jakarta: Penerbit Universitas Indonesia (UIPress).

Undang-Undang Republik Indonesia Nomor 7 Tahun 1992 tentang Perbankan.

Undang-Undang Republik Indonesia Nomor 10 Tahun 1998 tentang Perubahan atas Undang-Undang Republik Indonesia Nomor 7 Tahun 1992 tentang Perbankan.

Undang-Undang Republik Indonesia Nomor 21 Tahun 2008 tentang Perbankan Sharia.

\section{Copyrights}

Copyright for this article is retained by the author(s), with first publication rights granted to the journal.

This is an open-access article distributed under the terms and conditions of the Creative Commons Attribution license (http://creativecommons.org/licenses/by/4.0/). 